\title{
COMPARATIVE STUDY OF DIFFERENT IRRIGATION SYSTEM FOR COTTON CROP IN DISTRICT RAHIM YAR KHAN, PUNJAB, PAKISTAN
}

\author{
aMuhammad Y. Ali*, aShahid Saleem, aMuhammad N. Irshad, bAsif Mehmood, àadiha Nisar, amran Ali \\ ${ }^{a}$ Rural Education \& Economic Development Society (REEDS), Pakistan. House \# 1, St \# 1, Canal Park, Rahim Yar Khan, \\ Punjab, Pakistan. \\ ${ }^{b}$ Better Cotton Initiative (BCI), Office at House \# 1, St \# 1, Canal Park, Rahim Yar Khan, Punjab, Pakistan.
}

\section{ARTICLE INF O}

\section{Article history}

Received: January 14, 2020

Revised: April 25, 2020

Accepted: July 27, 2020

\section{Keywords}

Drip Irrigation

Sprinkler Irrigation

Flood Irrigation

Cotton
A B S T R A C T

The biggest responsibility of agriculture department is to produce food and cloth for huge population using the resource getting limited day by day. Water scarcity is most threatening among these limiting factors. New techniques are being developed day by day to increase the water use efficiency on farm level. Application of water directly in the plant root zone could save the water and curtail the losses pertinent to leach down and evaporation. Irrigation to soil does not control the climate variables and precipitation cannot be substituted to irrigation. Sprinkler irrigation system helps efficient utilization of water by using only when needed. This way not only losses made by leaching and evaporation are controlled but microclimate of the field is also ameliorated. Canals and tube well water is conventionally given to crop through flood irrigation. These fields are in direct threat of evaporation and leaching resulting in excess water losses and damaging the soil quality. The study was designed taking cotton as experimental crop to calculate comparisons in plant growth parameters and yields along with water saving ability of different irrigation system. Maximum income of Rs. 99403 was obtained from sprinkler irrigation while high yield of $990 \mathrm{~kg}$ and $753 \mathrm{~m} 3$ in comparison to T4, $736 \mathrm{~m} 3$ in comparison to T3 and $113 \mathrm{~m} 3 \mathrm{in}$ comparison to T2 was saved under drip irrigation system. The farmers are thus recommended to adopt sprinkler and drip irrigation system in order to get enhanced yields on sustainable bases and to curtail the water losses.

Corresponding Author: Muhammad Yousaf Ali

Email:yousaf_arsh@yahoo.com

(C) The Author(s) 2020.

\section{INTRODUCTION}

Cotton a kharif crop, produces soft white fibre boll which is enclosed in cover is economically important through the world is used as raw material for textile industry. In return it provides livelihood to farmer community, people involved in trade and processing. It belongs to family Malvaceae of Gossypium genus earlier grown as oil seed crop and protein source for animal feed. Cotton crop needs warm and humid climate, seed germination is affected by soil temperature as low soil temperature hinders proper seed germination (Hussain et al. (2020).

Agriculture is considered to be the largest sector of economy contributing $19.5 \%$ in gross domestic production (GDP) in 2019-2020, involving 50\% of labor force and being major source of foreign exchange. According to the Pakistan Bureau of Statistics, officially released Economic Survey of Pakistan report (20192020 ) by the government production of cotton is declined by $6.9 \%$ producing 9.178 million bales. 
Moreover, it was stated that limiting factor for agriculture growth was water shortage in both rabbi and kharif season which compelled farmers to remain below the production target [Economic Survey of Pakistan 2010-2020 highlights]. Variables found for cotton production are cost of cultivation, cost of seed \& sowing, cost of fertilizers \& pesticides, labor and irrigation. Irrigation and crop protection are of utmost important variables for production cost as described by Anwar et al. (2009).

Climate change and increase in temperature resulting in drought stress has limited the crop production. Change in pattern and rate of rainfall is creating drought around the world (Lobell et al. (2011). If drought becomes severe it not only affects the yield of crop but also alters plant physiology and reproduction. It is limiting factor for crop yield by affecting water availability for photosynthesis, nutrient availability and growth (Farooq et al. (2009), (Praba et al. (2009), (Iqbal et al. (2020), (Barnabás et al. (2008). Drought is declared if water supply to plant root is low or water losses through transpiration are high. Drought is result of change in various factors like moisture, soil capacity to hold moisture, rainfall pattern and evapotranspiration (Fahad et al. (2017). Adding above drawbacks of drought high temperature in filling days of seed can result in reduction of yield and quality. (Fahad et al. (2017).

Pakistan is amongst top cotton producing countries of world. In Pakistan Punjab and Sindh are major cotton producing provinces in addition small share is added by Baluchistan and Khyber Pakhtunkhwa too. Mostly areas under cotton crop are facing drought problems. Conventionally flood irrigation using canal water or tube well was practiced later ridge sowing was adopted to save water losses in flood irrigation. Now use of sprinkler and drip is becoming popular throughout world and in Pakistan too. To counter the yield loses caused by chewing insect Bt varieties are becoming popular in Pakistan but water as limiting factor is still a question. Throughout the world Bt is considered to be economically beneficial by reducing $80 \%$ of pesticide cost in comparison to ordinary cotton (Choudhary et al. (2016). To combat the drought problem water use efficiency should be increased for getting sustained yield. Furrows, drips, sprinkles are efficient irrigation systems and have increased water use efficiency potential among other irrigation systems (Zhai et al.
(2010) whereas drip irrigation system is superior over conventional irrigation methods (Sezen et al. (2008). There are several problems when dealing with surface irrigation or flood irrigation including salt accumulation after evaporation and leeching and difficulties in practicing cultural practices. Maximum dry matter production and plant height was gained using drip irrigation (Sampathkumar et al. (2006). The production of cotton can be increased by use of $\mathrm{Bt}$ varieties, fallowing proper spacing, adopting improved planting method, nutrient management and using water efficiently (Choudhary et al. (2016). Quality seed and fertilizers will come to nothing if crop isn't irrigated efficiently. Under drip irrigation 30\% increased seed cotton yield over sprinkler was obtained (Cetin and Bilgel (2002) while 10-19\% increased seed lint cotton yield was obtained with drip irrigation in comparison to furrow irrigation (Ibragimov et al. (2007), (Shirahatti et al. (2007). The world has upcoming threat of global food scarcity leading to poverty due climate change, it would be a great challenge to provide food and clothes to whole population around the world (UnitedNations, 2017). Water shortage is the problem of whole world; drip irrigation seems to be the only solution that can help us use the water efficiently as it provides a small amount of water only in root zone of plant frequently (Van der Kooij et al. (2013). Most of all drip irrigation system can be used in diverse topographies even where other irrigation systems cannot work (Wei et al. (2003). This study was designed to know qualitative and quantitative comparisons of cotton crop using different water application practices. The major objective of the study was to make the comparison of cotton crop under different irrigation systems.

\section{MATERIALS AND METHODS}

\section{Experimental site}

This Field experiment was carried out at Chak \# 99/1.L Tehsil Khanpur district Rahim Yar Khan during May, 2019 located between $28.65^{\circ} \mathrm{N}$ and $70.68^{\circ} \mathrm{E}$ and $97 \mathrm{~m}$ above sea level. Climate of this region is semi-arid and sub-tropical in nature due to average annual rainfall of 200-300 mm. Most of the precipitation is received during monsoon in month of July and August 2019. Average temperature of day and night during summer and winter months' ranges from $27-48^{\circ} \mathrm{C}$ and $7-21{ }^{\circ} \mathrm{C}$ respectively. 


\section{Detail of treatments}

There were five treatments i.e. T1 to T4 which are Drip Irrigation, Sprinkler irrigation, Flood Irrigation (canal water), Flood Irrigation (tube well water) \& Furrows/Ridges respectively.

Table 1. Detail of experimental treatments.

\begin{tabular}{ll}
\hline Treatment & Irrigation scheduling \\
\hline T1 & Drip Irrigation \\
T2 & Sprinkler irrigation \\
T3 & Flood Irrigation (Canal Water) \\
T4 & Flood Irrigation (Tube Well Water) \\
\hline
\end{tabular}

In first treatment $\mathrm{T} 1$ drip irrigation system was installed using canal water as irrigation source. In second treatment $\mathrm{T} 2$ three mobile sprinkler unites were used to irrigate the plant in the root zone at the rate of one emitter per plant. The water source was 40 feet underground water which was sucked by pump with one-inch outlet valve run using two solar plates energy. In third replicate T3 field was flood irrigated using canal water as source while in forth treatment $\mathrm{T} 4$ underground water using tube well was used to irrigate the field area.

\section{Seed Sowing}

In our experiment $8 \mathrm{~kg}$ seed of Bt variety SS 32 was used, sowing was done on May 10, 2019 at a row to row distance of 24 inches and plant to plant distance of 10 inches. Approximately 22000 plants of cotton per acre were calculated.

\section{Methodology}

The experiment was conducted in locality of district Rahim Yar Khan, experiment plots of one acre were selected for each treatment. Cotton variety SS-32 was sown in all plots on May 10, 2019. In each treatment 8 $\mathrm{kg}$ of seed was sown with row to row distance $(\mathrm{R} \times \mathrm{R})$ of 24 inches and plant to plant distance $(\mathrm{P} \times \mathrm{P})$ of 10 inches. The seeds started germination after 6 to 7 days on 16 to 17 May 2019. Average number of plants per acre was 22000 as shown in Table 1 . So it is clear that all the factor was kept same except irrigation system under which different experiment treatments were raised to evaluate the difference in results effected by these systems.

\section{Description of irrigation systems Drip irrigation system}

The drip irrigation system consisted of screen filter, main, sub mains, laterals and drippers. Drip was fed by a suction pump which sucks water from storage pond using solar energy. The main and sub main pipelines used for drip irrigation were made of PVC pipes of 50 $\mathrm{mm}$ and $25 \mathrm{~mm}$ diameter, respectively. Linear Low Density Polyethylene (LLDPE) pipes of $12 \mathrm{~mm}$ diameter were used for laterals in the treatment. Drippers having flow rate of $1.46 \mathrm{l} / \mathrm{h}$ were fitted on the laterals. One emitter per plant was used. The direction of the laterals was North-South. Moreover, the drip irrigation was used under canal water source which solved the problem of salt accumulation in the root zone. Canal water was stored in a pound and was used when required.

\section{Sprinkler irrigation system}

The system consists of mobile three sprinkler units of available model impact QY-99. Each sprinkler unit works with pressure equals to 60 PSI having nozzle size of $12 \mathrm{~mm}$ giving discharge of $30 \mathrm{~L} / \mathrm{M}$ per sprinkler. System works with pumps running on energy of two solar plates (150 watts each) to suck the water from 40 feet depth. Using one-inch delivery water pump it takes 4 hours for three sprinklers units to complete single irrigation of 2 Kannal areas. Timing of irrigation was decided using soil moisture meter KCB-300.

Three mobile sprinkler units were used to irrigate the field using 40 feet underground sweet water sucked up by electric pump of one-inch outlet and operated by two solar plates. Tube wells in this area suck brackish water from 60 feet depth.

\section{Flood Irrigation System (Canal Water)}

In experimental plot where flood irrigation was done using canal water as source. Irrigation was given to the filed considering soil moisture condition and crop requirement but keeping in view the availability of water according to farmers turns locally called Warabandi. It took about one hour to irrigate an acre.

\section{Flood Irrigation System (tube well)}

One of the experiment plots was flood irrigated using tube well water. Cotton crop was irrigated 8 times during whole growing season on the basis of soil and crop water requirements. While irrigating the experimental plot using tube well water it took 1.5 hour to flood irrigate an acre. In our experiment tube well motor of $10 \mathrm{HP}$ was operated using electric energy with outlet pipe size of 6 inches. Tube wells in this areas sucks water from 60 feet depth. 


\section{RESULTS AND DISCUSSION}

Crop was raised keeping all the experiment variables same to find the difference in crop response. The crop was monitored regularly, and data was tabulated. After the harvest of crop, the result was tabulated and analyzed. The tabulated inputs and findings are shown in table 2 and 3 (Annexure) in the end. Experiment variations in inputs applied and crop response for different treatments was observed as below:

\section{Input costs comparison}

We find differences in production cost and plant parameters for all four treatments. We have Rs. 4500 cost of seed bed preparation before sowing for T1, T3 and T4 while it was Rs. 4800 for T2. As seed rate per acre and variety was same so was cost of seed for all four treatments but there was difference in cost of fertilizer as maximum fertilizer cost was spent on T4 that was Rs. 10800 and minimum of Rs. 8150 was for T1 and T2 in comparison of Rs. 8550 for T3. Cost spent on weedicides per acre was same for $\mathrm{T} 1$ and $\mathrm{T} 2$ and was minimum too with Rs. 550 while maximum of Rs. 705 was spent for T4 it was Rs. 675 spent for T3. Most damaging is crop pests they damage $30 \%$ of crop production. Maximum cost of pesticides was Rs. 3860 for T4 and minimum was for T1 and T2 of Rs. 2685, cost of pesticide for T3 Rs. 3720 as shown in Figure 1.

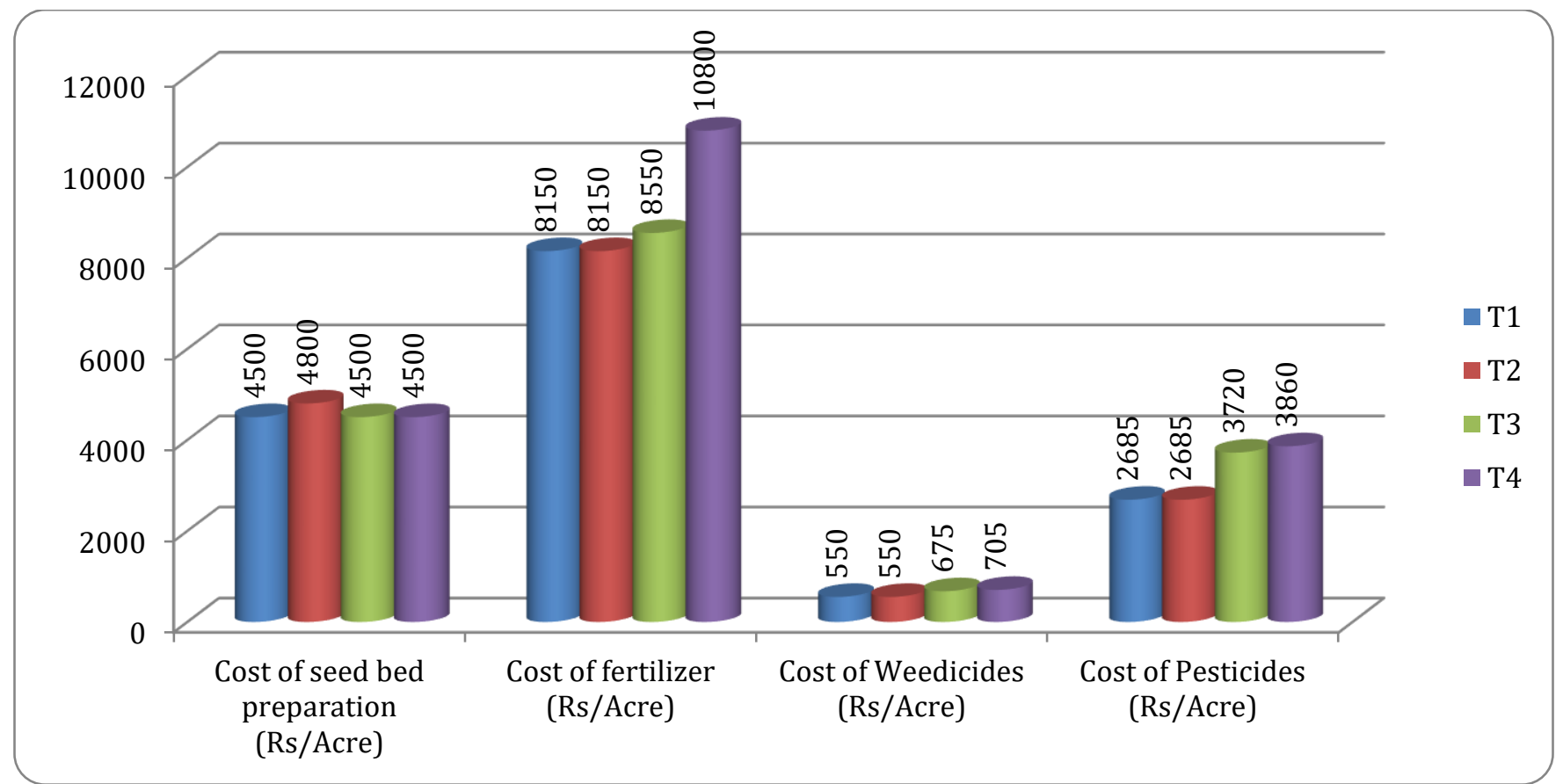

Figure 1. Input cost comparison.

\section{Plant parameters comparisons}

As for differences in plant growth parameters was concerned maximum average plant height of $137 \mathrm{~cm}$ was obtained in T3 while least average plant height was calculated as $120 \mathrm{~cm}$ for T1. This may be due to surplus water in $\mathrm{T} 3$, on the other hand continuous but limited water supply in T1 lead to early start of maturity stage and least plant height. The plant height for T2 and T4 was $135 \mathrm{~cm}$ and $134 \mathrm{~cm}$ respectively. Maximum number of branches was calculated in $\mathrm{T} 3$ and least in T1. Average number of bolls per plant were obtained in $\mathrm{T} 2$ was maximum and $\mathrm{T} 4$ was minimum counting 62 and 48 respectively. Duration of crop was 130 days in $\mathrm{T} 1$ and maximum of 142 days for T2 and T3, the crop under T4 lasts for 140 days as shown in Figure 2. 


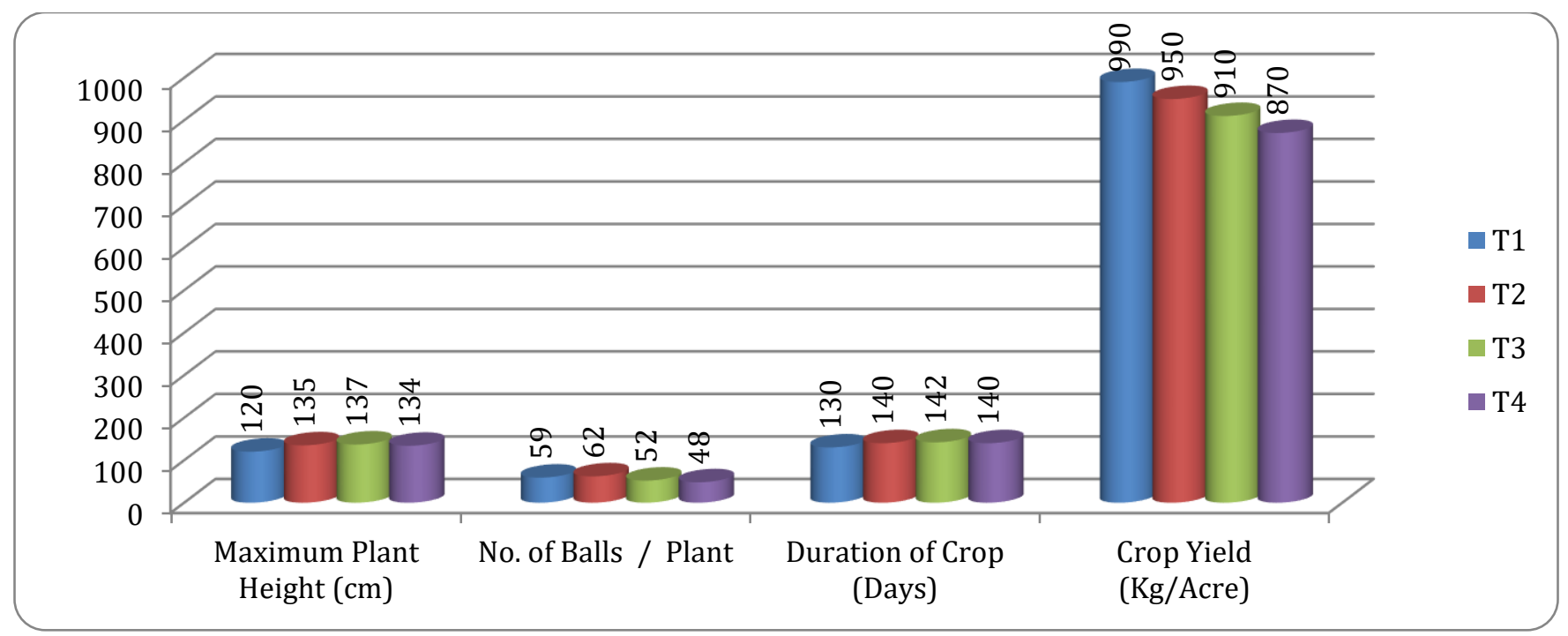

Figure 2. Plant parameter comparison.

\section{Water use comparison}

Water shortage is one of biggest challenges to world and Pakistan is becoming water scarce too. This is the time to adopt efficient water utilization approaches for saving the water for our future generations. It was found that minimum water was used in $\mathrm{T} 1$ for the whole season while maximum water was used for $\mathrm{T} 4$.
Water used for T2 was $600 \mathrm{~m} 3$. Maximum cost for water was spent for T4 which was Rs. 4550 but it was a low as Rs. 100 for T2 and T3 and Rs. 400 for T1. The price for T4 was high due to expense on energy source for tube well. It was calculated as $487 \mathrm{~m} 3$ of water was used in $\mathrm{T} 1,600 \mathrm{~m} 3$ for $\mathrm{T} 2,1223 \mathrm{~m} 3$ for $\mathrm{T} 3$ and maximum of $1240 \mathrm{~m} 3$ for $\mathrm{T} 4$ as shown in Figure 3.

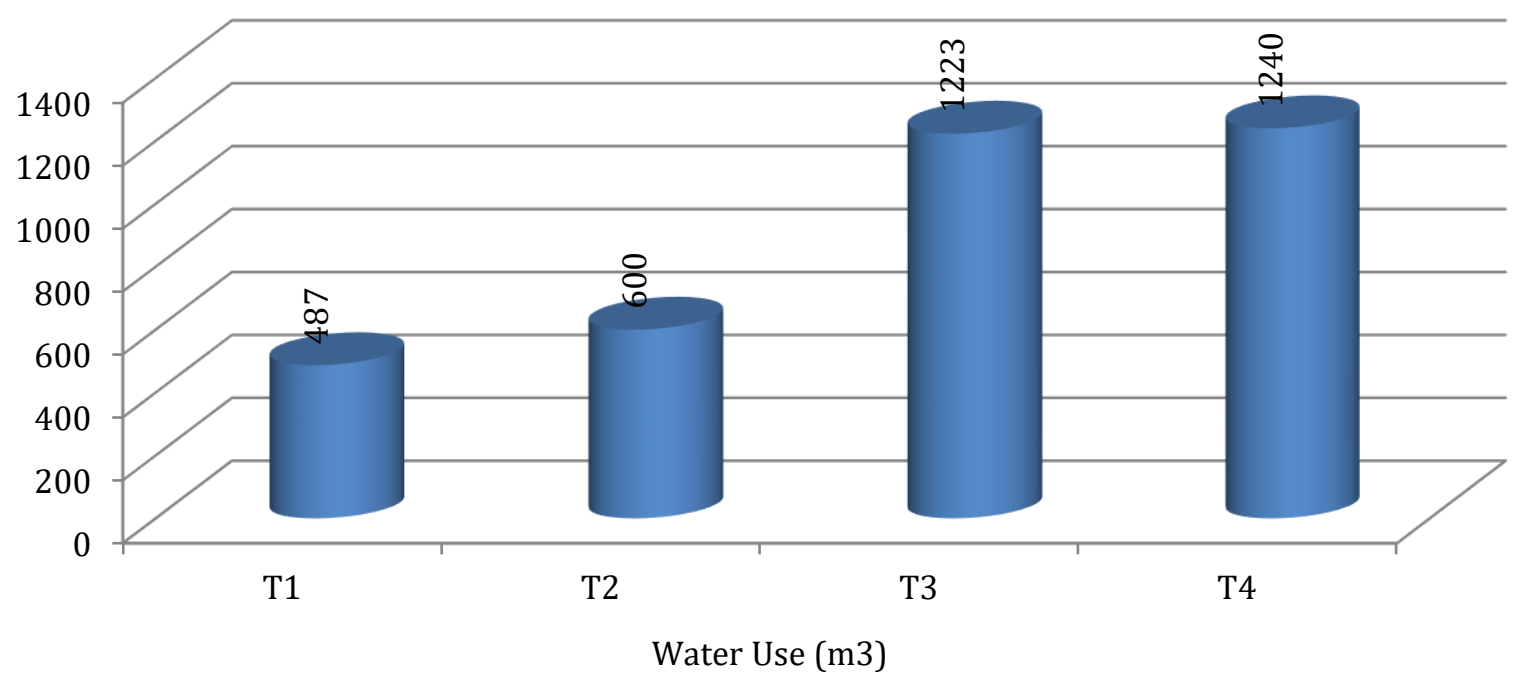

Figure 3. Water use comparison.

\section{Input cost and income comparison}

Total input cost depicts the cost spent on raising the crop it includes labour and input material cost together. This means it includes all the expenses of inputs (seed, water, fertilizers, weedicides and pesticides) and inputs application (seed bed preparation, seed sowing, fertilizers, weedicides, pesticides, and picking cost). The average price of cotton was about Rs. $4500 / 40 \mathrm{~kg}$ of seed cotton (Phutti). It was calculated as least input cost was spent 
for T2 which was Rs. 29972 and maximum for T4 which was Rs. 37702. For T1 and T3 total cost of inputs applied along with its application cost was Rs. 30122 and Rs. 31032 respectively. At the time of data collection, the price of cotton was Rs. 4500 per $40 \mathrm{~kg}$. The product from $\mathrm{T} 1, \mathrm{~T} 2, \mathrm{~T} 3$ and $\mathrm{T} 4$ was calculated to be of worth Rs 111375, 129375, 102375 and 97875 respectively. Calculating net income, we find T2 was best (Rs. 99403) in comparison to other three treatments. Net income from T1 was Rs. 81253 which was on second, least income was obtained T4(Rs. 60173) as shown in Figure 4.

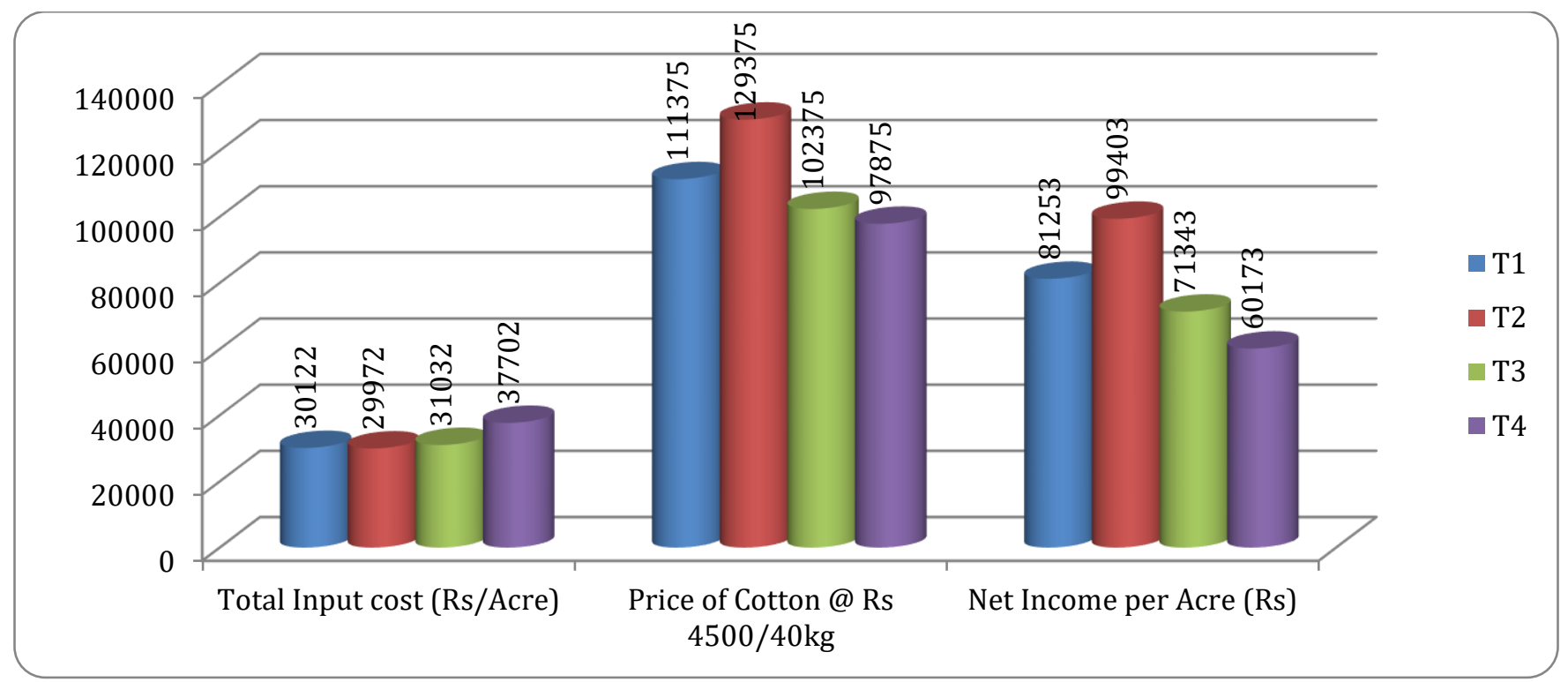

Figure 4. Input cost and income comparison.

\section{CONCLUSION AND RECOMMENDATIONS}

It is concluded that sprinkler was the best irrigation practice while drip uses least water to mature the crop due to its site-specific application. There were differences in input application for each treatment. Crop showed differences in growth parameters like plant height, number of branches per plant, number of bolls per plants and cotton yield. Drip and sprinkler have benefit of timely application, reduced cost of application, control of soil compaction problem, less exposure to chemicals (Pesticides and weedicides etc.), reduction in environmental contamination and improvement in crop response.

It is highly recommended to stop using the flood irrigation systems from any of the source like canal irrigation water or tube well water. Drips if used with canal water as source can overcome the problem of salt accumulation. Farmers can use sprinkler especially in initial 45-50 days after sowing which cover period of 34 irrigations and mostly canal water is not available in these days and hot summer is at peak. According to National Cotton Council, the period from Fruiting to Finish is important in maintaining the strong foundation for yield and fibre quality that was created during the first forty days. At 40 days after planting, the yield potential is already establishing, the crop should be healthy and uniform at this stage. Looking into the results from this field experiment it was found that drip irrigation is water saving and sprinkler enhances the yield from field trial. This is the time to promote the adaptation of water saving techniques and guide the farmer about importance of water management.

\section{REFERENCES}

Anwar, M., Chaudhry, I.S., Khan, M.B., 2009. Factors affecting cotton production in Pakistan: Empirical evidence from Multan district. Journal of Quality and Technology Management 5, 91-100.

Barnabás, B., Jäger, K., Fehér, A., 2008. The effect of drought and heat stress on reproductive processes in cereals. Plant, cell \& environment 31, 11-38.

Cetin, O., Bilgel, L., 2002. Effects of different irrigation methods on shedding and yield of cotton. Agricultural Water Management 54, 1-15.

Choudhary, K.K., Dahiya, R., Phogat, V., 2016. Effect of 
drip and furrow irrigation methods on yield and water use efficiency in cotton. Research on Crops 17, 823-828.

Fahad, S., Bajwa, A.A., Nazir, U., Anjum, S.A., Farooq, A., Zohaib, A., Sadia, S., Nasim, W., Adkins, S., Saud, S., 2017. Crop production under drought and heat stress: plant responses and management options. Frontiers in plant science 8, 1147.

Farooq, M., Wahid, A., Kobayashi, N., Fujita, D., Basra, S., 2009. Plant drought stress: effects, mechanisms and management, Sustainable agriculture. Springer, pp. 153-188.

Hussain, S., Mubeen, M., Akram, W., Ahmad, A., Habib-urRahman, M., Ghaffar, A., Amin, A., Awais, M., Farid, H.U., Farooq, A., 2020. Study of land cover/land use changes using RS and GIS: a case study of Multan district, Pakistan. Environmental Monitoring and Assessment 192, 2.

Ibragimov, N., Evett, S.R., Esanbekov, Y., Kamilov, B.S., Mirzaev, L., Lamers, J.P., 2007. Water use efficiency of irrigated cotton in Uzbekistan under drip and furrow irrigation. Agricultural water management 90, 112-120.

Iqbal, M.S., Singh, A.K., Ansari, M.I., 2020. Effect of Drought Stress on Crop Production, New Frontiers in Stress Management for Durable Agriculture. Springer, pp. 35-47.

Lobell, D.B., Schlenker, W., Costa-Roberts, J., 2011. Climate trends and global crop production since 1980. Science 333, 616-620.
Praba, M.L., Cairns, J., Babu, R., Lafitte, H., 2009. Identification of physiological traits underlying cultivar differences in drought tolerance in rice and wheat. Journal of Agronomy and Crop Science 195, 30-46.

Sampathkumar, T., Krishnasamy, S., Ramesh, S., Prabukumar, G., Gobi, R., 2006. Growth, nutrient uptake and seed cotton yield of summer cotton as influenced by drip, surface irrigation methods and mulching practices. Res. J. Agric. and Biol. Sci 2, 420-422.

Sezen, S.M., Yazar, A., Akyildiz, A., Dasgan, H.Y., Gencel, B., 2008. Yield and quality response of drip irrigated green beans under full and deficit irrigation. Scientia Horticulturae 117, 95-102.

Shirahatti, M., Itnal, C., Gouda, D.M., 2007. Impact of differential methods of irrigation on yield levels of cotton in red soils. Karnataka Journal of Agricultural Sciences 20, 96.

Van der Kooij, S., Zwarteveen, M., Boesveld, H., Kuper, M., 2013. The efficiency of drip irrigation unpacked. Agricultural Water Management 123, 103-110.

Wei, Z., Tang, Y., Zhao, W., Lu, B., 2003. Rapid development technique for drip irrigation emitters. Rapid Prototyping Journal.

Zhai, Y., Shao, X., Xing, W., Wang, Y., Hung, T., Xu, H., 2010. Effects of drip irrigation regimes on tomato fruit yield and water use efficiency. Journal of Food, Agriculture \& Environment 8, 709-713.

Publisher's note: EScience Press remains neutral with regard to jurisdictional claims in published maps and institutional affiliations.

Open Access This article is licensed under a Creative Commons Attribution 4.0 International License, which permits use, sharing, adaptation, distribution and reproduction in any medium or format, as long as you give appropriate credit to the original author(s) and the source, provide a link to the Creative Commons license and indicate if changes were made. The images or other third-party material in this article are included in the article's Creative Commons license, unless indicated otherwise in a credit line to the material. If material is not included in the article's Creative Commons license and your intended use is not permitted by statutory regulation or exceeds the permitted use, you will need to obtain permission directly from the copyright holder. To view a copy of this license, visit http://creativecommons.org/licenses/by/4.0/.

(C) The Author(s) 2020. 


\section{Annexures}

Table 2. Experiment details for all four treatments.

\begin{tabular}{|c|c|c|c|c|c|}
\hline Sr. \# & Parameters & T1 & $\mathrm{T} 2$ & T3 & T4 \\
\hline 1 & Cotton Variety & SS-32 & SS-32 & SS-32 & SS-32 \\
\hline 2 & Seed Rate (Kg) & 8 & 8 & 8 & 8 \\
\hline 3 & R x R Distance (inch) & 24 & 24 & 24 & 24 \\
\hline 4 & P x P Distance (inch) & 10 & 10 & 10 & 10 \\
\hline 5 & Sowing Date & 10-05-19 & 10-05-19 & $10-05-19$ & $10-05-19$ \\
\hline 6 & Germination Date & 17-05-19 & $17-05-19$ & 17-05-19 & $17-05-19$ \\
\hline 7 & Germination Time (Days) & 7 & 7 & 7 & 7 \\
\hline 8 & Type of irrigation System & Drip & Sprinkler & Flood & Flood \\
\hline 9 & Water Source & Canal & Ground Water & Canal & Tube well \\
\hline 10 & Emitter Per Plant & 1 & $\mathrm{~N} / \mathrm{A}$ & $\mathrm{N} / \mathrm{A}$ & $\mathrm{N} / \mathrm{A}$ \\
\hline 11 & No. of Plants / Acre (approx) & 22000 & 22000 & 22000 & 22000 \\
\hline 12 & Quantity of Urea (Kg) & 100 & 100 & 150 & 150 \\
\hline 13 & Quantity of DAP (Kg) & 50 & 50 & 50 & 50 \\
\hline 14 & Quantity of NP (Kg) & 25 & 25 & 0 & 0 \\
\hline 15 & Quantity of SOP (Kg) & 0 & 0 & 0 & 25 \\
\hline 16 & No. Pesticides used & 4 & 5 & 6 & 7 \\
\hline 17 & Maximum Plant Height $(\mathrm{cm})$ & 120 & 135 & 137 & 134 \\
\hline 18 & No. of Balls / Plant & 59 & 62 & 52 & 48 \\
\hline 19 & Crop Yield (Kg/Acre) & 990 & 950 & 910 & 870 \\
\hline 20 & Duration of Crop days & 130 & 140 & 142 & 140 \\
\hline
\end{tabular}

Table 2. Different experiment details like inputs applied and responses in crop parameters for different treatments.

\begin{tabular}{|l|l|l|l|l|l|}
\hline Sr. \# & Experiment Details & T1 & T2 & T3 & T4 \\
\hline 1 & Cost of seed bed preparation (Rs/Acre) & 4500 & 4800 & 4500 & 4500 \\
\hline 2 & Cost of seed (Rs/Acre) & 1200 & 1200 & 1200 & 1200 \\
\hline 3 & Cost of fertilizer (Rs/Acre) & 8150 & 8150 & 8550 & 10800 \\
\hline 4 & Cost of Weedicides (Rs/Acre) & 550 & 550 & 675 & 705 \\
\hline 5 & Cost of Pesticides (Rs/Acre) & 2685 & 2685 & 3720 & 3860 \\
\hline 6 & Water Use (m3) & 487 & 600 & 1223 & 1240 \\
\hline 7 & Cost of water (Rs/Acre) & 400 & 100 & 100 & 4550 \\
\hline 8 & Germination \% age & 75 & 72 & 72 & 70 \\
\hline 9 & Total Labour Cost in Rs = (i+ii+iii+iv+v) & 12637 & 12737 & 13487 & 13337 \\
\hline i & Labour cost for Irrigation (Rs) & 0 & 250 & 1200 & 1250 \\
\hline ii & Labour cost for Fertilizer application (Rs) & 250 & 300 & 300 & 300 \\
\hline iii & Labour cost for Weedicides application (Rs) & 250 & 250 & 250 & 250 \\
\hline iv & Labour cost for pesticides application (Rs) & 1000 & 1250 & 1500 & 1750 \\
\hline v & Labour cost for picking (Rs) & 11137 & 10687 & 10237 & 9787 \\
\hline 10 & Total Input cost (Rs/Acre) & 30122 & 29972 & 31032 & 37702 \\
\hline 11 & Price of Cotton @ Rs 4500/40kg & 111375 & 129375 & 102375 & 97875 \\
\hline 12 & Net Income per Acre Rs & 81253 & 99403 & 71343 & 60173 \\
\hline
\end{tabular}

